\title{
BE-WITH-ME-FOLLOWERSHIP SKILL: AN EXEGETICAL ANALYSIS OF MARK 3:13-19
}

Author ORCID: https://orchid.org/0000-0003-0140-7008

Author Affiliation: Seth Akhilele, $\mathrm{PhD}$

SC Classification Genre: Faith-based, Religion, \& Spirituality

Creative Commons Attribution (c) (1) (2)

Citation: Akhilele, S. (2021). Be-with-me-Followership Skill: An exegetical analysis of Mark 3:13-19. Scholar Chatter, 2(1), 32-43. http://doi.org/10.47036/SC.2.1.32-43.2021

(C) The Author. 2021. This is an open access publication through Scholar Chatter LLC.

\begin{abstract}
The paper focused on how followers can employ be-with-me-followership skill to glean information and directions from their leader or mentor to become who they ought to be. The 12 disciples' work relationship model with Jesus was adopted from the pericope Mark 3:13-19. Using a narrative approach, an exegetical analysis was employed to source data from the selected pericope. The exegetical data found was then intersected with the similar experiences of Elisha, Ruth, and Joshua. The lessons learned from the study include be-with-me-followership skill, drivers of be-with-me skill: realization that one has something to learn and seeing a mentor in a leader. Also, the study results showed that those who demonstrated be-with-me-followership skill eventually become who they ought to be. The study findings also revealed that adverse conditions and uncertainty could be used to test for subordinates/followers with be-with-mefollowership skill.
\end{abstract}

Keywords: Be-with-me-followership skill, leader, follower. 


\section{Introduction}

There is a perception that there are leader-follower working undercurrents that were used from time to time by Jesus and His disciples (King James Version, 1769/2017, Mark 3:13-19). Jesus is found in the pericope Mark 3:13-19 to have worked with His disciples with a clear instruction "be-with-me." The purpose of this study was to critically examine what the term "bewith-me" means to Jesus and His followers and how it can impact other organizations today. The reason for choosing this particular text, Mark 3:13-19 was because when one considers followership in scriptures, the be-with-me term is vivid here. The be-with-me term may be described as the staying ability of a follower that provides an enabling environment to learn from a leader or a mentor.

Osborne (2006) argued that narrative studies recognize that meaning is located in a text as a whole rather than in the form of distant segments. Osborne also suggested that biblical narrative involves redaction, form, source, and narrative criticism. The fundamental confidence of the usage of the biblical narrative is the idea of "read them." He claimed that it is when the story is read that one understands the drama and the power of the story, which will then fit together to yield a wholistic position.

The biblical narrative method supposes that the given text should be read. The study espoused by Osborne (2006) outlined literary critics' methods for close reading as a point of view. He claimed that this approach will enable the reader to detect flow and see the hand of God as inspired by the author. However, a more in-depth procedure that accommodate historical and literary dimensions was employed, which is structural analysis, narrative form, theological analysis, characterization, and contextualization.

\section{Literature Review}

Using some biblical text, one will attempt to review some related material on the subject matter, be-with-me-followership skills. Other texts examined included drivers of be-with-mefollowership skill and test of be-with-me-followership skills and the associated lessons.

\section{Be-With-Me-Followership Skill}

One can describe be-with-me-followership skill as the staying ability of a follower with a leader that allows the leader with enough time and resources to impart or transfer needed skills for defined organizational or team goals (King James Version, 1769/2017, Mark 3: 14-15). It means the availability of the follower. A follower can be around, available, or present enough with the leader for him or her to deposit or mentor him or her with what is necessary for the organization or team task. So, this suggests that the leader would want to mentor a follower; the question would be how available is the follower who desires mentoring. The skill that makes a follower available for full mentorship is what one can refer to as be-with-me-followership skill. Mentoring, on the other hand, can be described as a relationship in which a more experienced manager (leader) helps a less experienced protege (Yukl, 2013). Kowalski (1994) argued that to consent to be Jesus' disciple (follower) is to follow Him on His way, as His messenger sent to "net" people as a "fisher" for the Kingdom of God. Dale (1987) claimed that as followers, they 
learned to use their zeal to the broader concerns of the Gospel and their faithful dependency on Jesus for direction was noteworthy.

Kowalski (1994) argued that based on Luke's and the Church Tradition's esteem for Peter, that it can be concluded that the call of the Twelve as narrated by Luke: highlights Peter's dedication to Jesus, his commitment to work with Jesus and his instantaneous consent to change from catching fish to being a fisherman netting people for their salvation. Therefore, his role was to be the Lord's faithful and obedient helpmate in the task of proclaiming the "word of God". It indicates that the follower need commitment as a requirement to follow and learn from a leader.

Also, it is essential to say that the be-with-me-followership skill discussed here is the type that should come willingly from the follower. It is very different from when an individual is compelled to be trained on something. Even when others decide to leave a leader, followers with be-with-me-followership skill will remain (King James Version, 1769/2017, John 6:66-68) until they are trained to become what and whom the leader wants them to become. When the conditions become adverse, those without be-with-me-followership skill might leave the leader (King James Version, 1769/2017, John 6:66-68); While those with the be-with-me-followership skill will stay in adverse condition (King James Version, 1769/2017, Ruth1:8-19). The be-withme-followership skill precedes discipleship. One can only disciple who is with him. One can only disciple or mentor whom one sees (King James Version, 1769/2017, Mark 3:14). Jesus made it clear that for them to be able to learn all he had to teach them, they needed to stay with Him (be with Him).

The be-with-me-followership skill is what one commences with to follow a leader. Jooste and Frantz (2017). (2017) claimed that self-leadership fundamentally refers to being driven by motivation and self-influence to direct oneself towards achieving optimum performance in a situation. Leadership should be from within, and can thus be defined as authentic self-expression that creates value (Cashman,1998). One might say that a follower may not have gotten the necessary leadership skills but could still take the initiative to follow. Also, one may not have followed at all but through self-leadership could also take the initiative to lead self and achieve desired goals.

\section{Drivers of Be-With-Me-Followership Skill}

The realization that one has something to learn can make a follower stay. One can say that Peter left all that he greatly desired because he thought there was something beyond fishing that he could learn from Jesus (King James Version, 1769/2017, Luke 5:11). He was one of the 12 called by Jesus to be with Him (King James Version, 1769/2017, Mark 3:13-15). One can also see the account of Philip and Nathaniel. They followed Jesus because they believed. Nathaniel had even called Jesus Rabbi, meaning teacher. When a follower sees something uncommon that he can learn as in the case of Nathanael (King James Version, 1769/2017, John 1:47-50), he would want to stay with the leader. It implies that Nathaniel followed because there was something to learn from Jesus (King James Version, 1769/2017, John 1:44-49). For these disciples and others, one might say that the be-with-me-followership skill would be easy for them because they know there is something they could learn. Shaffer et al. (2012) claimed that 
mentoring has to do with a mentee showing that he or she wants to learn something new or improve his or her present knowledge base.

Seeing the leader as the right mentor can also be a motivation to stay. Jesus, at some point, asked the 12 disciples if they would also leave Him like others, their response was that they had no one else to go to because only Him had what they needed (King James Version, 1769/2017, John 6:66-69). One who wants to be made might want to stay with a leader because one is sure he or she is the right mentor. In other words, understanding that one is with the right person who will bring one to the desired destination. The follower thinks and sees the leader as someone that has something he does not have. For instance, Peter left his business to follow Jesus (King James Version, 1769/2017, Luke 5:1-11). Kowalski (1994) claimed that commitment to discipleship (followership) stresses the unconditional response of turning aside to a life that is new. It entails an instant response allowing for no hesitancy in this self-dedication. The Twelve's obedient response was deepened by their cooperation as Jesus' companions, as a standard for the way of "followers of Christ".

\section{Test of Be-With-Me-Followership Skill}

One of the ways the be-with-me-followership skill may be tested is through adverse condition and periods of uncertainty. Adverse conditions seem to be an experience that can assist to test one who has the be-with-me-followership skill. In the case of the 12 disciples, while Jesus taught on kingdom issues, which were regarded by some disciples as hard teachings, and for which reasons they left, the 12 disciples in their case chose to stay. According to Peter, he responded that they had no other person to go to because Jesus is the only one with the words of eternal life (King James Version, 1769/2017, John 6:48-68). It implied that the 12 had no choice but to continue to be with Jesus even when it did not seem to be convenient. So, while other disciples left, they stayed. They continued to be with Him even though it did not look convenient. One can say that though following looked challenging, they had a coping ability. Skinner et al. (2003) claimed that at the lowest level, coping responses are seen as numerous real-time actions people take to deal with stressful situations. On the other hand, when followers are unable to cope, they can revert to avoidance-focused coping approaches, such as taking leave (O’Driscoll et al., 2009; Yagil et al., 2011).

\section{Methodology}

The study was conducted by employing the methodology of narrative criticism. The exegetical analysis involved point of view, ideology, and the narrative world; structural analysis; theological analysis; characterization, contextualization; and the narrative form of the pericope, Mark 3:3-19. These are discussed extensively below to allow one to see the main message of the pericope. 
Point of view, ideology, and the narrative world: A cautious look at the pericope from the point of view reveals accordingly: Evaluative or ideological point of view:

1. On the concept of right and wrong, all the 12 Apostles obeyed to come to Jesus (King James Version, 1769/2017, Mark 3:14-15). Edmonds (2017) claimed that those appointed as the 12 are obedient to His invitation on the mountain "to be with Him," and to be sent out and to cast out demons.

2. The point of view of the crowd often draws them to Jesus, though mainly for them due to genuine faith in God (King James Version, 1769/2017, John 2:23-25, John 6:60-66); and the faith of the disciples leads them to follow Jesus despite the price (King James Version, 1769/2017, John 6:67-71). One can say that the proof that the disciples responded to Jesus in the positive was the ordination. Unlike the leaders in Israel and members of the crowd who had other intentions, these 12 choose to follow Jesus (King James Version, 1769/2017, Mark 3:13-15). One may say that if one truly wants to be trained, the right thing is for the individual to willingly follow the instructions of the trainer. In this pericope, Jesus is the instructor, while the disciples are those who are to be trained. Huizenga (2008) argued that Jesus truly was popular based on the early miracles signs and wonders as narrated in the Gospel according to Mark in Chapter 1. He therefore claimed that it is easy to follow Jesus under such conditions; On the spatial viewpoint of the bible narrative of the pericope, the passage showed that the narrator appeared to be "omnipresent" (King James Version, 1769/2017, Mark 3: 13-19). It is as if the narrator was close enough to observe and report all that transpired between Jesus and His disciples (Osborne, 2006). One can say that Mark was a bit authoritative in this account as one can deduce that he wrote as one at the scene of the event that transpired between Jesus and His disciples.

3. On the geographical setting, the passage under review showed that the matter of recruitment of the Apostles took place in a certain mountain around Jerusalem, Idumaea, Jordan, Tyre, and Sidon (King James Version, 1769/2017, Mark 3:8). Also, on temporal settings, the passage Mark 3:13-19 indicate that there is a form of temporal framework for the entire ministry training of Jesus for the disciples (Osborne, 2006). Jesus made it clear that the disciples were to be with Him for a while and would be sent out after some time. In other words, one might say that the teaching, mentoring, or coaching was timerelated. One would find actions such as instructions on roles assignment (King James Version, 1769/2017, Mark 3: 13-14). The pericope revealed that Jesus had roles He intends to make available to them upon completion of the training (King James Version, 1769/2017, Mark 3: 13-14).

\section{Structural Analysis}

The structural analysis of the pericope (King James Version, 1769/2017, Mark 3:13-19) showed the various activities that occurred in the recruitment or appointment of Jesus' 12 disciples. They include Jesus going to the mountains, the site of the recruitment (King James Version, 1769/2017, Mark 3:13); Jesus' call to the 12 and their obedience to the call to come to 
him (King James Version, 1769/2017, Mark 3:13); the ordination of the 12 (King James Version, 1769/2017, Mark 13:14); the outline of the job description of the 12:

1. To be with Him,

2. That they might be sent to preach,

3. Heal sicknesses and diseases and

4. Cast out devils.

\section{Theological Analysis}

It is clear from the entire course of recruitment and appointment of Jesus' 12 disciples that Jesus was the leader who instructed the 12 to come to him out from others (King James Version, 1769/2017, Mark 3: 13) and ordained the 12, which are: James, John, Andrew, Philip, Bartholomew, Matthew, Thomas, James the son of Alphaeus, Thaddaeus, Simon the Canaanite, and Judas Iscariot (King James Version, 1769/2017, Mark 3:14). It is also evident that Jesus told them the purpose of the ordination (King James Version, 1769/2017, Mark 3:17-19). On the relationship between Jesus and His disciples, Ewett (1984) argued that it could be said in the book of Mark that Jesus would not be the Christ in any noteworthy way, in any way that counted, without His relationships to people, primarily His relationship to His disciples. He opined that Jesus could not have been called the Christ at all without His disciples. He meant that to be the Christ, the Christ must have a people (Ewett, 1985).

\section{Characterization of Jesus and the 12}

Torneire (2019) claimed that Jesus showed a model for training Christian's disciples when He trained the 12 disciples for mission. He argued that Jesus identified, invited, selected, and sent an unlikely and underqualified group of ordinary men to seek the lost as they were going to proclaim and demonstrate the good news and good works, respectively. These claims resonate with what the Mark 3:13-19 pericope exemplify. The Gospel also signifies the disciples as his continuous companions from the first calling of some of them (Kilpatrick, 1982). Jesus is presented here as one who has a goal to achieve that was so great that other people would be needed for the task. He also knew that they needed to be with Him enough for him to send them for the task. On seeing Jesus as a coach or teacher, Bird (1981) argued that Mark intentionally developed the picture of Jesus as a teacher as against a Christological counterpoint of Jesus as just a miracle worker.

One can see from the pericope, Jesus, as a leader willing to empower others and also with an ability to allow others to participate in a common process (Yukl, 2013). Jesus can also be described from the pericope under consideration as one who will prepare and delegate a task to a subordinate and not abandon him on the job.

On the 12 disciples, Camille (2018) argued that these are not self-selected seekers but rather those personally invited by Jesus to be part of His mission. One can see this from the pericope Mark 3:13-19, that Jesus was the one who called them. They did not apply for the job to follow and become something. MacAskill (2011) argued that in addition to the accounts of the 
calling of specific disciples, there is also the account of the appointing of the apostles. There is an important point to note in Mark 3:3-19, namely, that the 12 constitute a special group within the broader community of disciples. The uniqueness of their apostolic office is important. They are called to a distinctive form of service, one that may depart significantly from the experience most of us will have (MacAskill, 2011). Ewett (1985) argued that as the disciples, the representative leaders of the "new" people of God, respond to Jesus' call and became insiders to whom the mystery of the Kingdom is communicated. Ewett believed that the 12 disciples are the ones Jesus wanted to hand over His mission on earth to.

Camille (2018) claimed that the term disciple suggests they are students of His "way": faithful or hungry enough to stay for some time, to accept whatever it is Jesus was teaching. These 12 disciples were told they needed to stay with Him and learn. Kilpatrick (1982) suggested that certain developments are consistently presented by the Mark account of the Gospel. He is of the view that after Jesus' baptism, He made Capernaum his headquarters. He established himself in a house called His disciples and breaks with his family and the Jewish leaders, including the Pharisees. Robertson (1936) claimed that they were called to become fishers of men and left their business to follow Jesus all the time. They were required to have a thorough knowledge of Jesus and to be able to teach others what they had themselves learned (Robertson, 1936). Robertson (1936) claimed that these men had now been with Jesus for over a year and by the third year, as seen in Mark 6:7. It was time for these men to try their hand at preaching and healing. In essence, one can say that Jesus called or appointed the 12, to train them, and deploy them for service. However, one can also say that they were meant to stay or be with Him for this dream to be realized. Ewett (1985) claimed that while it is clear that the relationship between the disciples and Jesus, in Mark's account, is a fundamentally tensive relationship; however, he argued that how it should be placed is still a subject of debate among Markan school scholars.

\section{Contextualization}

The implication of the pericope Mark 3:13-19 is that anyone who wants to lead people for a task can get them together, train them with a detailed job description. So, one can see that the content or course curriculum was built on their job description. It meant that the course content was on:

1. Sending them to preach

2. Having power to heal sicknesses

3. Casting out devils

The be-with-me requirement, was a criterion for the realization of the first three (King James Version, 1769/2017, Mark 3:14-15).

\section{The Narrative Form of Mark 3: 3-19}

On the 12 and their staying with Jesus, Camille (2018) claimed that a genuine encounter with Jesus is a life-changing experience. One can then say that the narrative is that Jesus needed 
a close team to work with to execute what God had asked him to do. However, He was not going to do it alone. So, He selected a team, and developed a curriculum to train them. Staying with Him was a necessity for the training to occur. One can also see that the 12 obediently came to Jesus from the midst of other worshipers and followers.

\section{Findings}

The exegetical analysis of Mark 3: 3-19 led to results such as staying with the leader as a condition for training, what Jesus was willing to teach his disciples, and Jesus' willingness to empower. These are explained in details below:

\section{Be-With-Me-Followership Skill}

Jesus identified the 12 disciples He wanted to work with and decided that staying with Him was a criterion necessary for training them (King James Version, 1769/2017, Mark 3: 13-19). He took them into a house, which suggests a place of training (King James Version, 1769/2017, Mark 3:19).

\section{What Jesus Was Willing to Teach His Disciples}

Jesus is clear in the pericope on what He wanted His disciple to be trained on. In other words, Jesus had a training curriculum for the 12 disciples (King James Version, 1769/2017, Mark 3:14-15).

\section{Jesus' Willingness to Empower}

The analyzed pericope indicates that Jesus was also willing to empower the 12 disciples after the training. Hence, the text showed that He was willing to send them to preach, heal, and cast out devils (King James Version, 1769/2017, Mark 3:14-15).

\section{Discussion}

Jesus' training model is clear from the pericope, Mark 3:13-19. He had the selection of His followers done, had a curriculum but saw staying with Him as the criteria for their training. It appeared that the be-with-me requirement was the condition that was going to allow the delivery of the curriculum He had. The said staying ability is what one will want to see as a skill necessary for getting trained from the leader.

One can also employ the account of Ruth and Naomi (Moabites) to corroborate the test of be-with-me-followership skill of the 12 disciples of Jesus. Ruth and Oprah had lost their husbands, just like their mother-in-law, Naomi. Naomi was returning to Bethlehem-Judah. By reason of marriage, they were both meant to follow Naomi anywhere she chooses to stay or go. Naomi knew she could not bear any more children because of age and asked them to return to their people. While Oprah returned, Ruth instead told Naomi not to entreat her not to follow her. She claimed she was ready to go anywhere with her, lodge where she lodges, make Naomi's people her people and die where Naomi chooses to die, to be separated only by death, and finally make Naomi's God her God (King James Version, 1769/2017, Ruth 1:8-18). One can say that there was something that Ruth saw in Naomi that Oprah did not see that made her want to be 
with her even in an unpleasant situation. Also, a true be-with-me-followership skill will survive adverse conditions. The resultant effect of Ruth's staying with Naomi lead to a mentoring process that got her a husband (Ruth 3:1-18), and she ended up as part of Jesus' genealogy (King James Version, 1769/2017, Matthew 1:1-16).

Joshua is another example of a follower that had be-with-me-followership skill. Joshua was known to serve Prophet Moses in the task of taking the Israelites to the promised land. At very critical times, such as going to meet with God, Moses wanted Joshua around (King James Version, 1769/2017, Exodus 24:13). Some of these meetings may take days or weeks, yet Joshua will wait until Moses was done with God in the mountain. Another account indicated that after a significant visitation of the people in the camp and everyone might have retired, while Joshua, the young man, remained, and did not depart from the tabernacle. He was probably waiting until Moses says he was done for the day (King James Version, 1769/2017, Exodus 33:11). One might not be surprised that God told Moses to lay hands-on Joshua because he had the spirit (King James Version, 1769/2017Numbers 27:18). One can say that a follower with a be-with-mefollowership skill will likely end up becoming what his mentor was or even more prominent. One will not be surprised that it was this Joshua that succeeded Moses. So, one can say, just like Jesus' command to His disciples, was follow me and I will make you (King James Version, 1769/2017, Matthew 4:19); Joshua followed, and stayed with Moses until he was made (became Moses' successor).

Be-with-me-followership skill can also be demonstrated in periods of uncertainty. Prophet Elisha is another person who had the be-with-me-followership skill like the 12 disciples. He was a known mechanized farmer who abandoned his profession to follow the Prophet (King James Version, 1769/2017, 1Kings 19:19-21). It implies that he was waiting on Elijah, or he was always where Elijah was. However, there came a severe period of the test of his faithfulness, that was when Elijah wanted to depart (King James Version, 1769/2017, 2Kings 2:1-15). Elijah told Elisha to wait for him in Gilgal because God has sent him to Bethel, he refused. At Bethel, Elijah made him realize he needed to go to Jericho, and he should wait in Bethel, but he refused that he will not leave Elijah. At Jericho, he advised him to stay behind.

Nevertheless, he vowed to follow him (be with Him) to Jordan while all these happened at Bethel, Jericho, and Jordan other sons of the prophets confirmed to Elisha the reality of Prophet Elijah's final departure. However, Elisha was not moved and vowed to stay with his boss until the end, even in a period of uncertainty. In the end, Elijah asked him to state what he wanted, and he asked for a double portion of his anointing. Elijah responded that it was a hard request but that it will only be possible if he, Elisha saw him being taken. Eventually, that happened, and the mantle fell on Elisha. So, it suggests that a follower who stays well enough with his leader or mentor might be able to step into the shoes of his mentor/leader (King James Version, 1769/2017, 2Kings2: 13-15).

On the contrary, the same Elijah had a servant that he left behind in Beersheba at a time of the persecution of Jezebel (King James Version, 1769/2017, 1kings 19:1-3). The servant whose name was not given, did not make any attempt to be with him in his trying moment. One can say that the said servant has no be-with-me-followership skill. Today, his name is not known 
because he was not made like Elisha. One can say, anyone that cannot follow will not be made or known.

Jesus in His words declared that "If any man serve me, let him follow me; and where I am, there shall also my servant be: if any man serve me, him will my Father honor" (King James Version, 1769/2017, John 12:26). One can relate to these declarations of Jesus as one looks at the main pericope of this study, Mark 3:13-19 on the be-with-me-followership skill of the 12 disciples, Ruth, Joshua, and that of Elisha. So, here, Jesus made it clear that anyone who serves Him should do two things: follow Him and be where He is. So, one cannot expect to serve, follow, or be mentored without first being where his or her leader is when needed. The follower can then receive honor in return for staying. One can say that honor can come in terms of succession, promotion, skills, and so on.

One can also say that be-with-me-followership skill could be described as a heart connection between a leader and a follower that enables the leader to impact the follower, while the follower learns. Also, vital is that one might say that it is beyond being around a leader. One can be around and not connected to the leader. The connection should be strong enough to allow for impartation and empowerment on the part of the leader. The follower's main role is to follow-around enough or connect enough to be imparted and empowered (King James Version, 1769/2017, Mark 3: 1769/2017, Mark 3:14-15).

\section{Conclusion}

One can say that the be-with-me-followership skill is what is needed by many subordinates or followers to be able to get all they need from their leaders to become what they are meant to be. The study shows that there are followers that may not be able to stay with the leader and depart for reasons known to them. One can also see from the study that there are followers/subordinates despite the pressures/adversities who remained with their leaders/mentors to have the necessary trainings. Also, it is important to state that individuals examined and found to have demonstrated the be-with-me-followership skill all became made or had their work status changed. One can, therefore, recommend the be-with-me-followership skill to all followers who desire to become great like their leaders. For future research, a quantitative, or qualitative study can be conducted in organizations to verify the results of this study.

\section{Funding}

The research for this article was funded solely by the author.

\section{Acknowledgements}

Thanks to the almighty God for inspiration to write. I will want to appreciate my wife, Josephine Akhilele for the moral support. Also, my thanks go to Dr. Julie Conzelmann [Dr. Jules] for the encouragement to publish. I will not forget Professor Bruce Winston who advised me to consider publishing this paper while reviewing my work as a $\mathrm{PhD}$ student, thank you. 


\section{References}

Bird, P. A. (1981). The inspiration of scripture: Problems and proposals By Paul J. Achtemeier Philadelphia, Westminster, 1980. Theology Today 38(1), 104-107. https://doi.org/10.1177/004057368103800119

Camille, A. L. (2018). Testaments: The inner circle. U.S. Catholic, 83(7) 47-49. https://uscatholic.org/july-2018/

Cashman, K. (1998). Leadership from the inside out: Becoming a leader for life. Berrett-Koehler Publishers.

Dale, R. D. (1987). Leadership - Followership: the church's challenge. Southwestern Journal of Theology, 29(2), 23-28. https://swbts.edu/school/school- of-theology/southwesternjournal-of-theology

Edmonds, P. (2017). Mark's Gospel: Discipleship and formation. The Way a Review of Christian Spirituality Published by the British Jesuits, 56(1), 9-22. https://www.theway.org.uk/websubs/561.pdf

Ewett, R. 1. (1985). The Christology of Mark: Hermeneutical Issues for Systematic Theology. Semeia, 30, 125-153. https://ixtheo.de/Record/1649962312

Huizenga, L. A. (2008). Solus Christus: the Markan contrast between Jesus and his disciples. Currents in Theology and Mission, 35 (6), 405-412.

Jooste, K. \& Frantz, J. (2017). Self-leadership traits of academics to conform to a changing higher-education environment. African Journal of Health Professions Education 9(4),199 https://doi.org/10.7196/ajhpe.2017.v9i4.823

Kilpatrick, G. D. (1982). Jesus, His family and His disciples. Journal for the Study of the New Testament, 5(15), 3-19. https://doi.org/10.1177/0142064X8200501501

Kowalski, W. (1994). The call to discipleship: A Challenge to personal commitment. Academic Journal, 36(6), 366-378.

MacAskill, G. (2011). The twelve (Mark 3:13-19). Theology of Work Project. www.theologyofwork.org

O’Driscoll, M., Brough, P., \& Kalliath, T. (2009). Stress and coping. In S. Cartwright, \& C. Cooper (Eds.), The Oxford handbook of organizational well-being, pp.237-266. Oxford University Press.

Osborne, G. R. (2006). The hermeneutical spiral: A comprehensive introduction to biblical interpretation (Rev. and expanded, 2nd ed.). InterVarsity Press.

Robertson, A. T. (1936). Christ's call for preachers. Review \& Expositor, 33(3), 251-259. https://doi.org/10.1177/003463733603300302 
Shaffer, F., Crawford, J., \& Moss, D. (2012). Mentoring: What Is It All About Anyway? Biofeedback, 40(3), 99-101. https://doi.org/10.5298/1081-5937-40.3.07

Skinner, E. A., Edge, K., Altman, J., \& Sherwood, H. (2003). Searching for the structure of coping: A review and critique of category systems for classifying ways of coping. Psychological Bulletin, 129(2), 216-269. https://doi.org/10.1037/0033-2909.129.2.216

Torneire, M. (2019). As we go. Lutheran Mission Matters, 27(1), 162-172.

Yagil, D., Ben-Zur, H., \& Tamir, I. (2011). Do employees cope effectively with abusive supervision at work? An exploratory study. International Journal of Stress Management, 18(1), 5-23. https://doi.org/10.1037/a0020548

Yukl, G. A. (2013). Leadership in organizations. Pearson Education, Prentice Hall. 